\title{
Sustainable Heritage Development: Learning from Urban Conservation of Heritage Projects in Non Western Contexts
}

By

\author{
Dr. Amira Elnokaly ${ }^{1}$ and Dr. Ahmed Elseragy ${ }^{2}$
}

\begin{abstract}
Urban conservation has been a subject of academic and professional discourse for over three decades. Conservation in this paper is seen as an umbrella term that covers a wide spectrum of issues that can be classified under three categories: socio-physical, sociocultural, and environmental concerns. It is also manifested as a process of evolutionary development which involves preserving, restoring, and adapting old structures, while introducing new ones; a process that respects the continuity of history and tradition, the needs of inhabitants and their cultural aspirations. This understanding indicates that urban conservation is a process of continuous yet controlled interventions in the environment. The extent and the degree of such an intervention is dependent upon crucial factors that include the value system adopted by the society, the resources available, and the cultural and environmental context within which such an intervention takes place. With an ultimate goal to discern lessons from urban conservation practices, urban rehabilitation and adaptive re-use is discussed with reference to a number of non-western case studies. The paper aims at exploring the merits of six conservation and rehabilitation projects which have received considerable coverage and recognition on a national and international level while they have not been put into contextual comparison with others. Merits of these projects are analyzed and highlighted in this article to work as an archetype for similar projects around the world. The paper concludes that to maintain sustainability of the revitalisation and urban conservation approaches, the typical urban tissue and essential qualities of the historic areas and of the life of the communities residing there should be maintained, while adapting the physical structures and activities to some of today's requirements.
\end{abstract}

Keywords: Cultural sustainability; Sustainable heritage development; Belonging and identity; Sustainable urban Conservation; Rehabilitation and revitalization; Environmental quality; Non-western contexts; Strategies and strategic plans.

1. Senior Lecturer, Program Leader Msc Sustainable Architectural Design Lincoln School of Architecture, University of Lincoln, United Kingdom, Tel: +44 1522837178

2. Associate Professor, Arab Academy for Science Technology and Maritime Transport, Founder and Director at IBEX (International British Exchange for Knowledge and culture)

Tel: +44 7803516683 


\section{Introduction}

Environmentalists, economists, architects and urban designers, and even politicians worldwide are now preaching for conservation and especially urban conservation, each for his/her own purpose and in fact in his/her own terminology. The premise of this paper is that while there have been a considerable debate within the developed world on urban conservation, efforts that were undertaken in the developing world do not seem to have been sufficiently addressed in recent discussions. The concomitant result is a lack of knowledge about the realities of urban conservation in developing countries, which may lead, in turn, to miss opportunities for learning from outstanding urban interventions in non-western contexts. The physical environment in nonwestern contexts reflects the intersection between place, culture, society, and the available technology. Typically, it encompasses a range of well established traditions and practices where the symbols of religious, political, institutional, and economic powers are often competing. After the Second World War, re-building of old urban areas of historic cities occurred across Western Europe in the 1950s and into the 1960s that led to a much greater awareness of the unique character of these older areas and the need to treat them sensitively and constructively. (Graber, 1993) Urban conservation in those countries is generally understood as a process of continuity and change which forms the backbone of any urban culture and society.

Projects identified for this study are selected from Egypt, Palestine, Tunisia and Uzbekistan. These were selected based on their scale, scope of interests, contextual constraints, and the economic realities of their localities. Thus, the methodology adopted is to analytically compare these projects based on the criteria for selecting them. Another methodological mechanism is undertaken based on a cross case study analysis and content analysis procedure of the literature on these projects. Within such an analysis, issues underlying the three categories of socio-physical and socio-cultural and environmental concerns are debated. The procedure involves identification of key parameters amenable to and normally associated with successful urban conservation projects. These include participation and democracy in decision making, providing educational and job opportunities; re-building local communities, raising the standards of living, socio economic development, rapprochement of tourism and culture, developing adaptive re-use schemes and environmental awareness programs. The analysis indicates that urban conservation is a process of change and development rather than romanticism or radical redevelopment. In essence, the projects analyzed emphasize a number of successful indicators which could help establish guidance for undertaking future urban interventions exemplified by infill and conservation projects in similar contexts. The results of implementing this multilayered 
methodology offers important lessons that could be adopted yet adapted to both western and non western contexts.

\section{Sustainable Urban Conservation: A Medium for Change}

Urban conservation of heritage sites in cities contributes largely towards upgrading environmental quality, thus serving as a fundamental catalyst for change. Lichfield (1988) defines two main motivations for conservation which are resource value and responsibility towards the others respectively. Resource value is an important value for conserving existing stocks since; in general term, conservation of historic stocks saves more resources (that is a sustainable approach), than the construction of new ones, especially when the quality of those stocks is generally superior to the new ones. (Tiesdell et al.,1996) Responsibility towards the others is another value that led certain countries to act as trustees not only for future generations but also for non-nationals around the world. Concomitantly, historic stocks are considered trust to be kept and delivered for others. In that sense Steinberg (1996) argues that due to a good number of local conservation groups and the existence of international cultural organisations, such as the United Nations Educational, Scientific and Cultural Organisation (UNESCO), the International Centre for the Study of the Preservation and Restoration of Cultural Property (ICCROM) and the International Commission on Monuments and Sites (ICOMOS) monuments have at least a "lobby" and are in a somewhat more favourable situation than urban historic sites and residential areas.

The above organisations offer some success in their efforts to achieve greater interest for the course of preservation and conservation of old monuments of historic value. However, in the course of concern over "monuments" this often excludes historic residential areas and historic city centres which equally represent the urban heritage. In addition, to other cultural non-tangible elements of urban heritage such as: customs and beliefs. These non-tangible elements play a key role for the articulation of complex space use and the built environment. (Hampikian, 1999) Development projects taking place in historic districts tends to attract a variety of economic activity and competition, therefore encouraging both new inhabitants and visitors to revisit and rediscover these restored vicinities of their cities. Moreover, upgrading the physical built environment, social fabric and urban spaces within the historical urban structure all contribute towards increasing their adoption as places for public congregation and activity. This consequently increases social interaction and cohesion between citizens. Furthermore, conservation and regeneration of historic sites most evidently located at city centres tends to re-affirm residents' feelings of identity and sense of belonging. 
Furthermore, urban conservation in its broader term preserving tradition, social and cultural aspects as well as the physical improvement of historic buildings is often witnessed as an approach towards higher levels of sustainability. According to Stren and Polese (2002), one of the main aims of sustainable urban policy is to "bring people together, to weave parts of the city into a cohesive whole, and to increase accessibility (spatial and otherwise) to public services and employment (Stren and Polese, 2000)." In addition, sustainable areas are those which are created to support sustainable living, with a prime focus being placed on economic, social and environmental sustainability. (McDonald et al., 2009) This is of distinguished importance in historic districts (quarters) which tend to represent and symbolise a diverse set of ideals of the city's identity, including its history and culture on one hand, and its local economic viability on the other. (Elnokaly, A, et al, 2007)

In spite of the fact that in 1979 the UNESCO has listed historic Cairo in UNESCO World Heritage List, However, it is not till the last decade when there has become a genuine alertness and interest in Cairene urban heritage. (Sutton et al. 2002) Albeit, there have been several successful urban conservation projects on different levels, the political commitment is still lacking or very difficult to obtain, and even the concerted efforts of international and national heritage organisations have not been able to generate such support. (Antoniou et al. 1985) Cairo has benefited only from a number of rather isolated cases of monument restoration, financed, for instance, by foreign archaeological institutes and other bilateral donor agencies and due to lack of that political support has missed out on a World Bank loan. (Lewcock, 1984)

However, it is not the intention here to provide a comprehensive analysis of all previous attempts and aspects that hinders some of the projects, but the aim is to analyse two particular successful projects named below in this paper. Furthermore, investigating the issue of cultural sustainability and sustainable urban conservation in these projects is of crucial significance to this paper.

\section{The Nature of Conservation}

With the increasing argument over global warming and climate change, Conservation as a process of sustainable development in historic cities has been the subject of many debates in recent years. Although academics and practitioners applaud the new awareness of environmental concerns, some scholars argue that these apprehensions are still not enough to adequately address the problems of conservation. Concomitantly, the authors assert that any conservation policy or practice needs to incorporate economical, social and cultural sustainability into its current models.

Conservation in American Heritage Dictionary (AHD, Ed., 2005) means the act of conserving. It is defined as the controlled use and the systematic 
protection of resources, restoration of natural or built environments and the ecological environments that inhibits them. When tracing the term conservation in the literature that has been developed over the last two decades one can find that it has several dimensions. Some definitions offered in physical terms by Feilden (1982) identified seven degrees of intervention arguing that the minimum the intervention the better the conservation. These terms are prevention of decay, preservation, consolidation, restoration, rehabilitation, reproduction, and reconstruction. Salama (2000) argues that these terms are currently used interchangeably, which makes the understanding of the nature of conservation difficult.

For the purpose of this paper the definition provided by Donald Appleyard (1977 \& 1979) that introduced a broader classification in physical and social terms is seen as the most significant one to be used for the projects analysed in this study. He identified three classes of interventions. These are: 1) deep conservation, which attempts to restore a historical area in a rigorous and accurate form, 2) surface conservation, which attempts to maintain the public face or the physical appearance of a historic building or area, and 3) deep social conservation, which attempts to ensure jobs for local inhabitants, controls rents, and provides new services and amenities. Consequently, conservation is presented in both a dynamic and active sense, and this implies that it generates an overall environmental improvement in a historic area.

A common feature in all six projects analysed in this paper and as discussed in some of the literature (Ashworth, 1997, Andreae, 1996) is that they all adopt the belief that any physical improvement of a historic building or area should go in parallel with preserving traditions and cultural values, eradicating poverty, creating employment opportunities, and improving the standards of living while proposing a new use of some of the buildings. Cultural values are seriously considered in the Convention for the Safeguarding of the Intangible Cultural Heritage (2003) includes immaterial aspects as symbols of cultural diversity that should be protected as well.

\section{Methodology}

This paper aims at scrutinizing several successful conservation projects that have been carefully selected in historic cities that includes, Al Darb Al Asfar project, and Darb Qirmiz Quarter Project in old Cairo, Egypt, Conservation and reconstruction of Hafsia Quarter II, and conservation project of Sidi Bou Said Village both in Tunisia. The other two projects include Restoration of Bukhara old city, Bukhara, Uzbekistan and the conservation of Hebron Old town, Hebron Palestine. These six case studies have been selected on the basis of national and international recognition as contained in the AGA Khan Trust awards. A 
narrative approach is used to present each case study and cross case analysis was used to compare the findings and merits of each case.

\section{Conservation Projects in Old Historic Cities}

Over the past 50 years many studies, projects, and planning proposals have been made to conserve historic, heritage sites in different parts of the world. In the following sections we are going to analyse six different projects that involves conservation, restoration, rehabilitation and reconstruction from four different countries.

\subsection{Learning from Cairo's Sustainable Urban Regeneration}

The first two projects this article looks at are in Cairo, Egypt. Campbell and Comodromos (2009) proposed a radical vision for the future of the alleyway communities (hawarri) of heritage sites of old Cairo: with their own analysis and understanding of the complex spatial organization of old Cairo, they have abstracted this knowledge into "speculative skyscraper that verticalizes the complex interrelationship of informal social networks and urban/civic form. Their design reduced the community to a spatial and morphological abstraction, in a layered stratum of services and land uses that ascended in social significance to the mosque at the top. (Campbell and Comodromos, 2009) They believed that this would simulate the complex social interactions and norms present within the medieval fabric of Islamic Cairo, utilizing accepted characteristics that had been "reinforced in the sub- conscious of the population over centuries." Shehayeb (2007) argues that a bottom-up methodology approach is the best methodology to be uptaken in conservation projects of historic cities and most specifically in Cairo which is disregarded in their proposal. This is supported by Bianca (2000) and Rodwell (2007) concept where they both argue that - authenticity - is the backbone of modern conservation philosophy and practice, based on consistent information sources. For Architects and consultants that are not aware of the regions in which conservation and rehabilitation is undergone, data collection and inquiries include a qualitative in-depth survey aiming to assert everyday life-style patterns in the neighbourhood, as well as what the residents valued most in their area. The typical relationship between socio-spatial setting and architecture in Old Cairo has further been described by Stephen Kern (2003) as comprising a "path" that is "closed by masonry." "The Egyptians conceived of space as a narrow path down which the individual soul moves to arrive at the end before ancestral judges. Their most distinctive constructions are not buildings but paths enclosed by masonry," which represents the alleyway and the narrow street of the harrah (alley). Kern (2003) observation would thus disagree with the abstraction of all 
the socio-spatial complexity of old Cairo's everyday life in the proposal by Campell and Comodromos.

In Similar vein, Rodenbeck (1983, p. 26) argued that to save monuments in isolation from their 'environment', i.e., the spatial quality of urban fabric, was a sterile waste of time. There was an urgent need to recapture old Cairo's "size, splendour and dynamism" in a more holistic way. To further reinforce this suggestion, Lewcock (1989, p. 8), responding to the 1980 UNESCO Plan, argued that "it was felt that it was the uniqueness of ensemble that was the real quality of Old Cairo. Individually, the buildings are not all masterpieces, but collectively their character is strong and fascinating". This approach was challenged during the 1980s for the Gamaliya area by Abdel Fattah and Abdelhalim (1989), who advocated renovation through demolition. They argued that $60 \%$ to $65 \%$ of the buildings (excluding monuments) "must be regarded as ripe for redevelopment", which meant ready for demolition. They further advocated that a certain amount of gentrification was inevitable along with greater traffic access to Old Cairo with more parking availability, as it would produce economic returns. (Sutton and Fahmi, 2002) This rehabilitation approach of demolition has been demonstrated for the 1990s by Aboukorah (2005) for the Al-Ghuriya quarter where, despite the permanency of the street pattern, numerous new buildings of sometimes up to 8 or 10 storeys have been constructed. In addition, other older buildings have been altered through the addition of further storeys, thus affecting the city's skyline and urban fabric. This approach often tended to block the traditional self organization of local communities which used to function for centuries. Additionally, it sacrificed traditional institutions and systems in favor of a more centralized and bureaucratic ones that does not have the tools to deal with the intricate and complex problems in the historic city. (Bianca 2004) Sedky (2009) define the most important factor that might be responsible for the decline of historic cities to a psychological/culture nature in regards to the negative impressions and attitudes towards the historic districts which were mainly influenced by the interpretation of the Western concept of Modernism.

\subsection{Al Darb Al Asfar Project}

The project of Al Darb Al Asfar exemplifies a real experiment for limited restoration, but wider conservation (Shehayeb and AbdelHafiz, 2006). The idea of a home in this historic urban space has long involved fluid socio spatial associations and made efficient dynamic use of space, activity and time. As other areas of heritage and cultural value, the area surrounding Al Suhaymi House (Bayt $\mathrm{Al}$ Suhaymi) depicted in Figure 1 in $\mathrm{Al}$ Darb $\mathrm{Al}$ Asfar alley of $\mathrm{Al}$ Gamaliyah district in old Cairo was neglected for years. However, it has acquired a new image recently along with other distinguished houses in the alley. There were 3 main 
houses in the alley that were rehabilitated and restored and these were Al Suhaymi House (1648), Mostafa Gaafar House (1713), and Al Khorazati house, a living example of residential architecture of the 19th century, they were then all allocated adaptive functions to fit within the wider development of the area. (Bianca and Siravo, 2005) Architects working in such sensitive heritage contexts must understand the dynamics of this complex traditional system, if they are to develop locally informed functions, genuine designs that build on everyday local practices and the wider regeneration strategy for the area.

Man's relation to locales, and through locales to spaces, inheres in his dwelling, the relationship between man and space is none other than dwelling, thought essentially.

-Martin Hiedegger

The notion of the dynamic use of space and the understanding of locale is seen here as the key to a successful restoration and conservation of AlDarb Alasfar. In 1994 documentation and preservation processes started, based on a Fund from Arab Association for Social Development. (Abada, 2000) After restoration they were then all allocated adaptive functions to fit within the wider development of the area. As restoration proceeded in the three houses the surroundings were also improved, including infrastructures such as electricity, water, and sewage systems that were all renovated. The project adopted implicitly the integrated urban conservation approach, and employed many of the concepts underlying cultural sustainability. (AKTC, 2005) The community of the alley was encouraged to design ways to keep their neighbourhood clean and pleasant, providing a vehicle for environmental awareness. Via a participatory approach, regular meetings were held with over 100 families to discuss various aspects of renovation. This has resulted in the neighbourhood forming a society for preserving the character of the alley and maintaining the quality of life they aspire to.

The integration of social, physical, and environmental work in conservation represents an integrated approach toward conservation and can be replicated in other comprehensive projects in old Cairo and elsewhere in the World. Although this project is an exemplar that represents a culturally sustainable urban conservation process (AKCS-E, 2003), the challenge of implementing other project proposals undertaken by several organizations remains to be seen unreachable. 


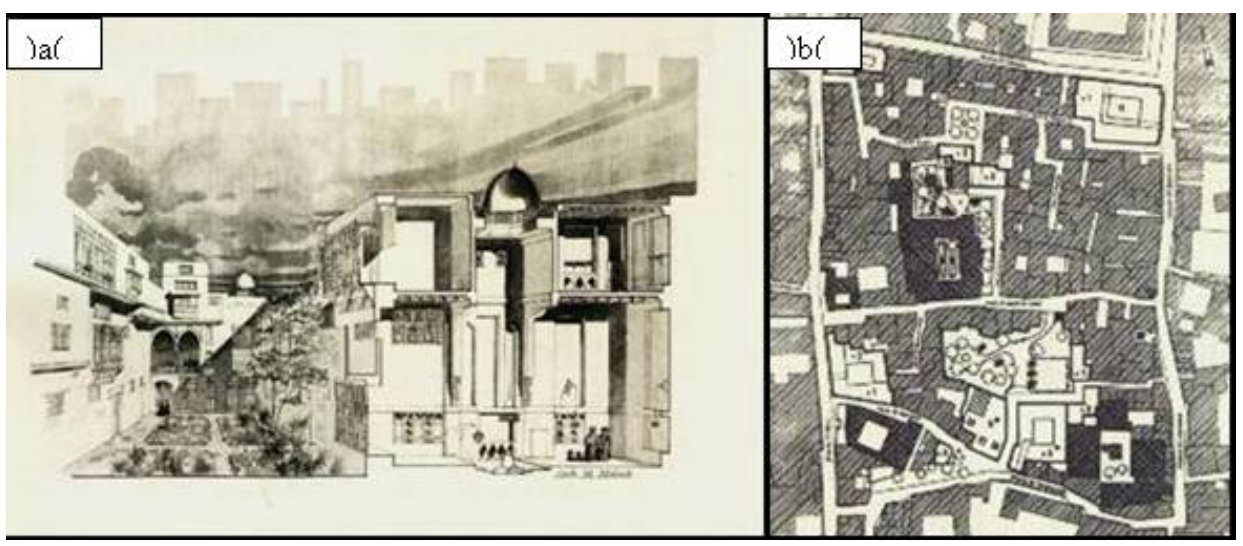

Figure 1. (a) Perspective cross section of AlSuhaymi House (b) The Master plan of AlDarb Alasfar, (After: Salama, 2000)

\subsection{Darb Qirmiz Quarter, Cairo, Egypt Completed in 1980-1983}

The Darb Qirmiz is a residential neighbourhood in the 10th-century Fatimid quarter of Cairo is shown in Figure 2. The major monuments of the district, the oldest dating from the 14th century, follow a narrow meandering street that bisects the neighbourhood. They include three madrasas, a palace, mausoleum, fountain and bazaar (Williams, $2002 \mathrm{~B}$ ). The restoration of all seven monuments has been planned as the first step in the rehabilitation of the larger area (AKAA, 1983). The award honours the completion of Phase I which includes the restoration of the Madrasa of al-Anuki, a Mamluk building dating from A.D. 1368, and the Mausoleum of Sheikh Sinan, dating from A.D. 1585. (Lewcock, R., 1983) The conservation work included the replacement of corroded stone and loose plaster surfaces, and the repair or replacement of all damaged decorative work, carpentry and original painted surfaces in the original techniques and materials. The project has employed the finest masons, plasterers and carpenters left in Cairo thus supporting inevitable local skills. The jury commended "the high quality and purity of the restoration work evident throughout and its positive value for the surrounding community." 


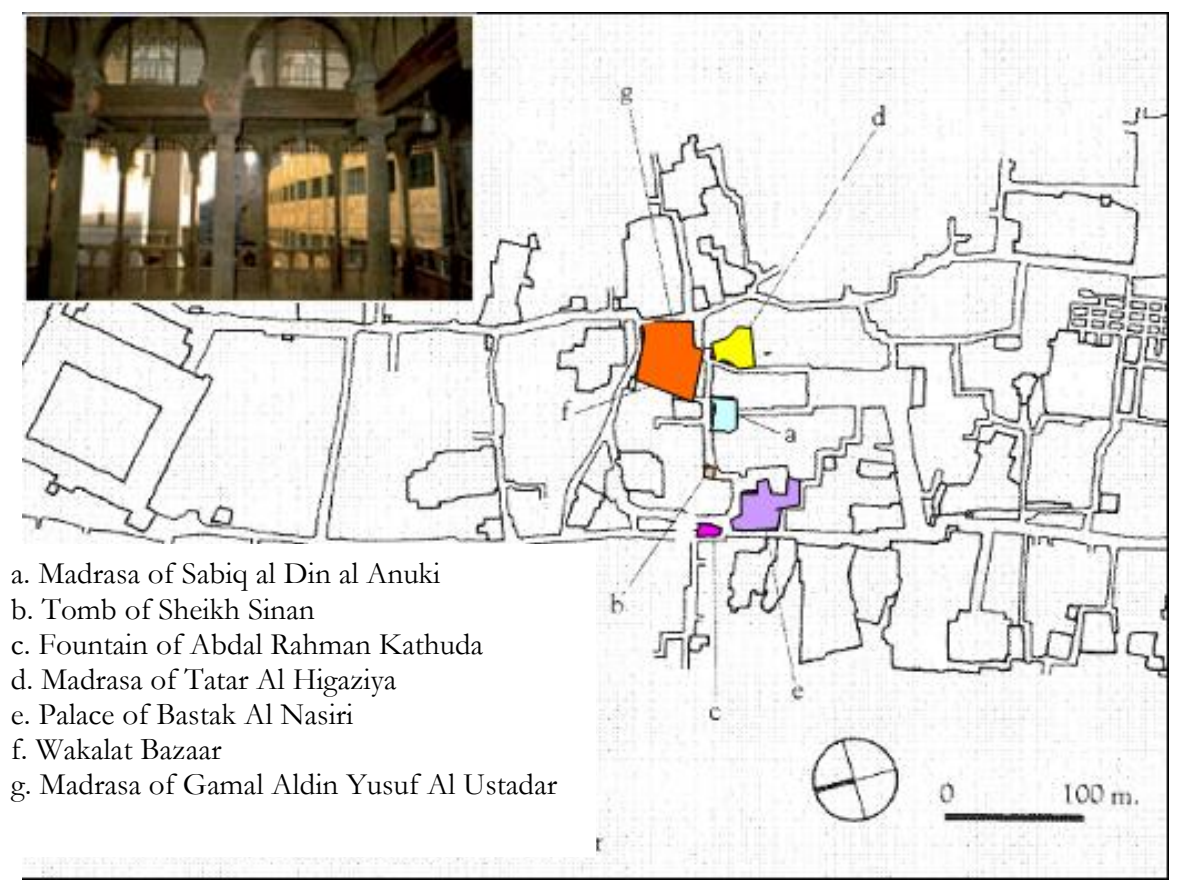

Figure 2. Darb Qirmiz Quarter and buildings that undergone rehabilitation and restoration (After; AKAA 1983)

\subsection{Restoration of Bukhara Old City, Bukhara, Uzbekistan Completed in 1975}

The old city of Bukhara was founded 2,500 years ago. Within its ancient city walls and gates are 500 standing monuments: they include 24 madrasas, 48 mosques, 14 caravanserais, 9 mausoleums, 4 trading domes, the Ark citadel, and many hammams, old houses, and canals (AKAA-a, 1995). The restoration programme began in the late 1960's under the USSR, and has been continued by Uzbekistan since its independence in 1990. The primary aim is to conserve the major monuments and landmarks in the centre of the old city, and to re-integrate them into the life of the bordering districts depicted in Figure 3. Because most of the upgraded mosques, madrasas, mausoleums, and other monumental structures are no longer used as such, a new function was found for each. Some madrasas, for example, have been turned into craft centres, studios, and galleries. One has become a restoration institute where future restorers are trained. Other structures have had their old functions renewed.

A caravanserai is a silk and cloth warehouse revitalised, and trading domes are renewed as active suqs. Among the great landmarks restored are the Samanid Mausoleum, the Mir-i Arab Madrasa, and the Kalyan Minaret. 


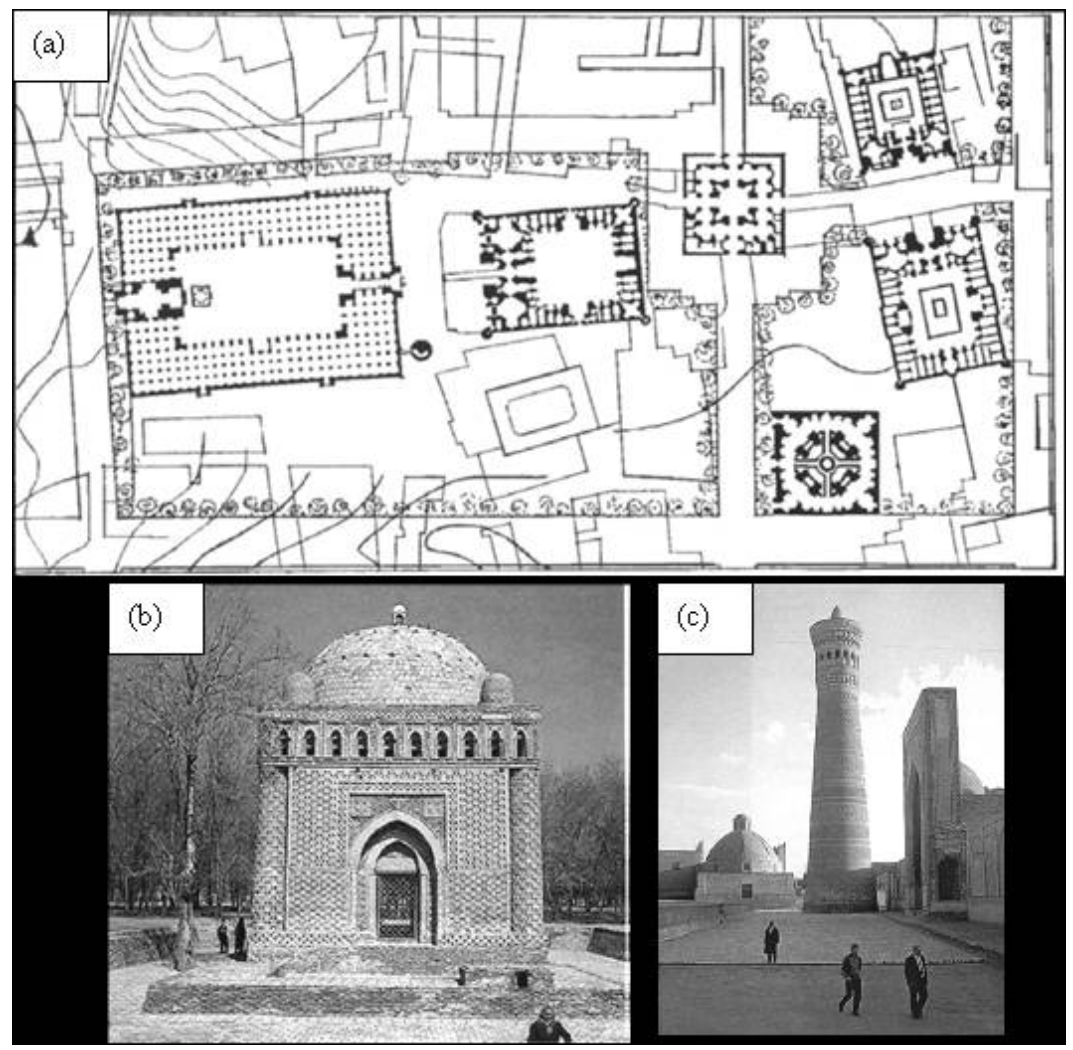

Figure 3. (a) Central Bukhara Restoration Plan; (b) Samanid Mausoleum built in the 9th-10th centuries; (c) The Poi-Kalyan built between the 12th and 16trh century, After: (AlRadi 1995)

To open up the old centre, thereby allowing the monuments to be better seen, mediocre buildings of the 1950's were removed. Utilities have been upgraded, and the streets paved. Old Bukhara, no longer a derelict slum, is now a viable prosperous city. (AlRadi, 1995) The Aga Khan (AKAA-a, 1995) jury believes that "the restoration of Bukhara sends a very strong message to the rest of the Islamic world of the need to restore and re-integrate old cities into new ways of life."

\subsection{Reconstruction of Hafsia Quarter II, Tunis, Tunisia Completed in 1986}

The Hafsia Quarter is located in the eastern part of the old Medina of Tunis. Once a wealthy district, by the early 1960's it had deteriorated badly. In 1967, the Association de Sauvegarde de la Médina was established to study and protect the urban fabric of the old city of Tunis, and improve the living conditions of its inhabitants. The first phase of the reconstruction of Hafsia, 
completed in 1977, received the Aga Khan Award for Architecture in 1983 (AKAA-b, 1995).
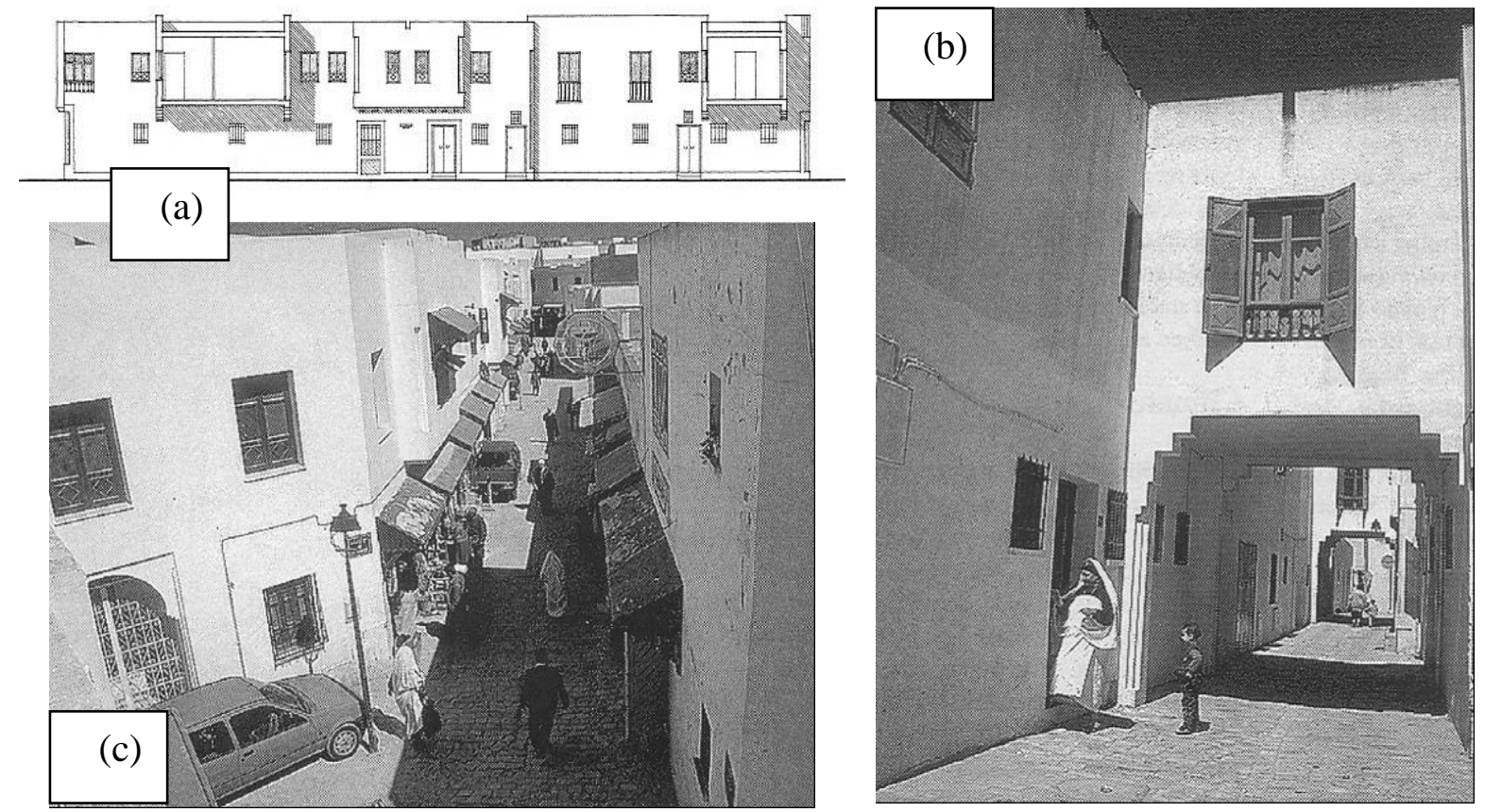

Figure 4. (a) Decorative elements emphasise the exterior of houses in the long whitewashed houses facades (From: Davidson, Cynthia, 1995); (b) View from roof top of a kindergarten; (c) View of Rue Errakah (Photos courtesy: Fadel, R., 1995)

The current phase is the continuation of this work, and builds upon the earlier experience. It includes the upgrading of the existing water services and main utilities, and the rebuilding of roads and access routes, as well as the reconstruction of housing, shops, offices, and public facilities. In addition to the rehabilitation of existing dwellings, 400 new housing units have been constructed. These units adopt the traditional model of two-storey blocks arranged around an internal courtyard. The architectural vocabulary employs traditional elements such as mashrabiyya, partially covered streets, and accentuated corner details as seen in Figure 4. This simplicity of expression not only relates to the historic context, but adds unity to the development, and responds to budgetary constraints. In dealing with such issues as appropriate institutional development, needed legislative changes, and effective financial implementation, the jury found the collaboration and inter-disciplinary co-ordination expended on Hafsia II to be exemplary. (AKAA-b, 1995) The experience gained and the solutions that evolved are relevant to all the varied problems faced by those who wish to save the historic old cities in today's Islamic world. 


\subsection{Conservation of Sidi Bou Saïd, Tunis, Tunisia Completed in 1973}

This former summer resort village has become a year-round residential area of Tunis. Built on a hill above a magnificent cliff and the Bay of Carthage, the natural beauty of the site enhances the interest of the town. Its urban fabric sure similar to Le Tourneau (in Raymond 1994) comments on the Muslim city in the Maghreb as he describes the buildings, instead of being integrated into a planned design, have forced the streets to turn round them, or to cut through them, as best as they could. The buildings are a mix of Mauresque and some Italianate elements organised contiguously along a tangled pattern of streets surrounding the central mosque and suq seen in Figure 6.

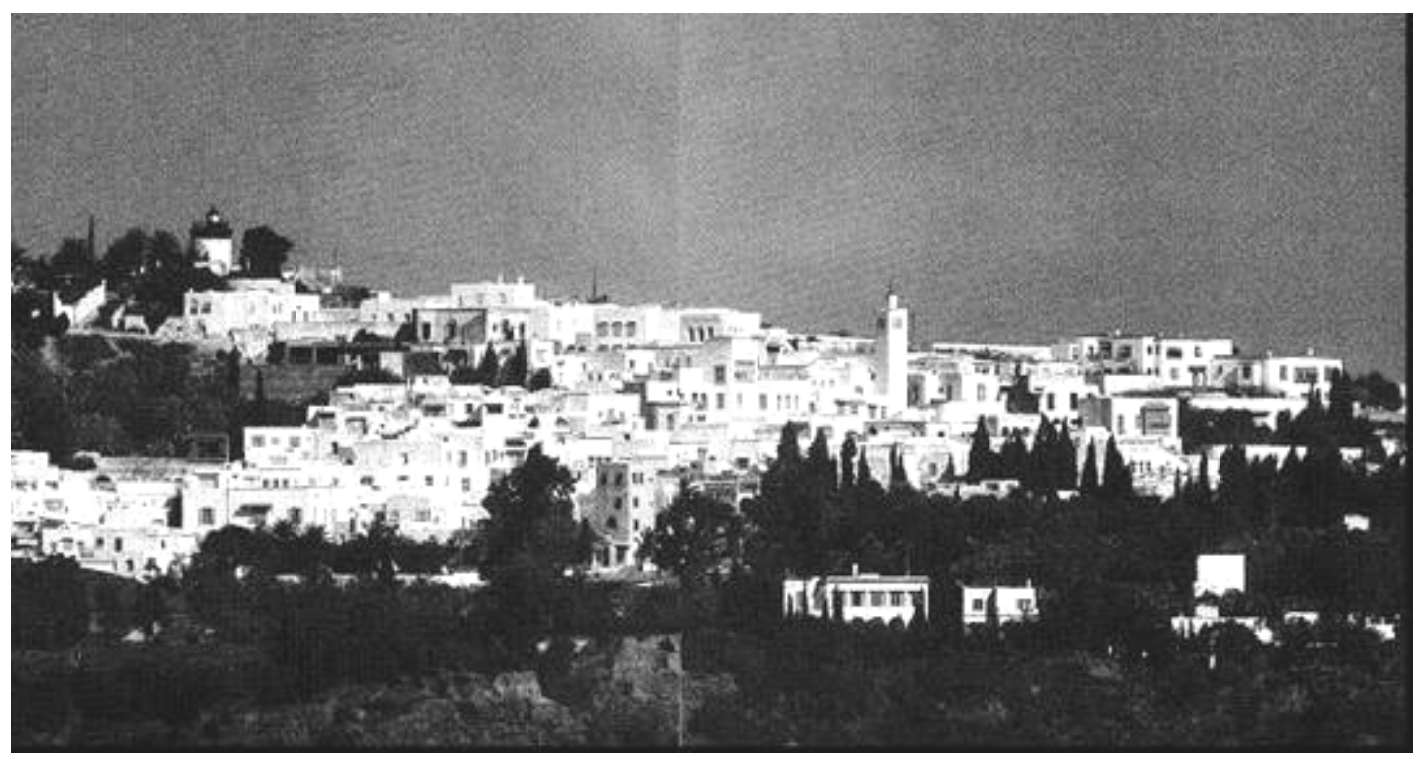

Figure 5. An Overview of Sidi Bou Said from the Southeast, (From: Holod, Renata and Darl Rastorfer. 1983)

The coming of mass tourism brought increasing pollution and traffic congestion. Moreover, the latter posed a serious threat to the geological stability of the cliff. A management plan prepared by the District of Tunis, enacted in 1978, sets directions for the control of development and land use (AKAA, 1980).

The town depicted in Figure 5 received a citation from the Aga Khan jury "for the efforts over a long period of time by a community toward the conservation of

their village. Based on true understanding of the architectural values of the village, legislation has been enacted controlling maintenance, expansion and vehicular circulation, and the sense of place has been kept. (AKAA, 1980) The conservation of the village maintained Hakim (2001) five core pillars for the ongoing process of growth and change within a city. These five pillars are: 
freedom; control; tolerance; adjustment; custom and tradition of the local community. In essence, Sidi Bou Saïd has retained not only the picturesque quality of a village, but its very essence".
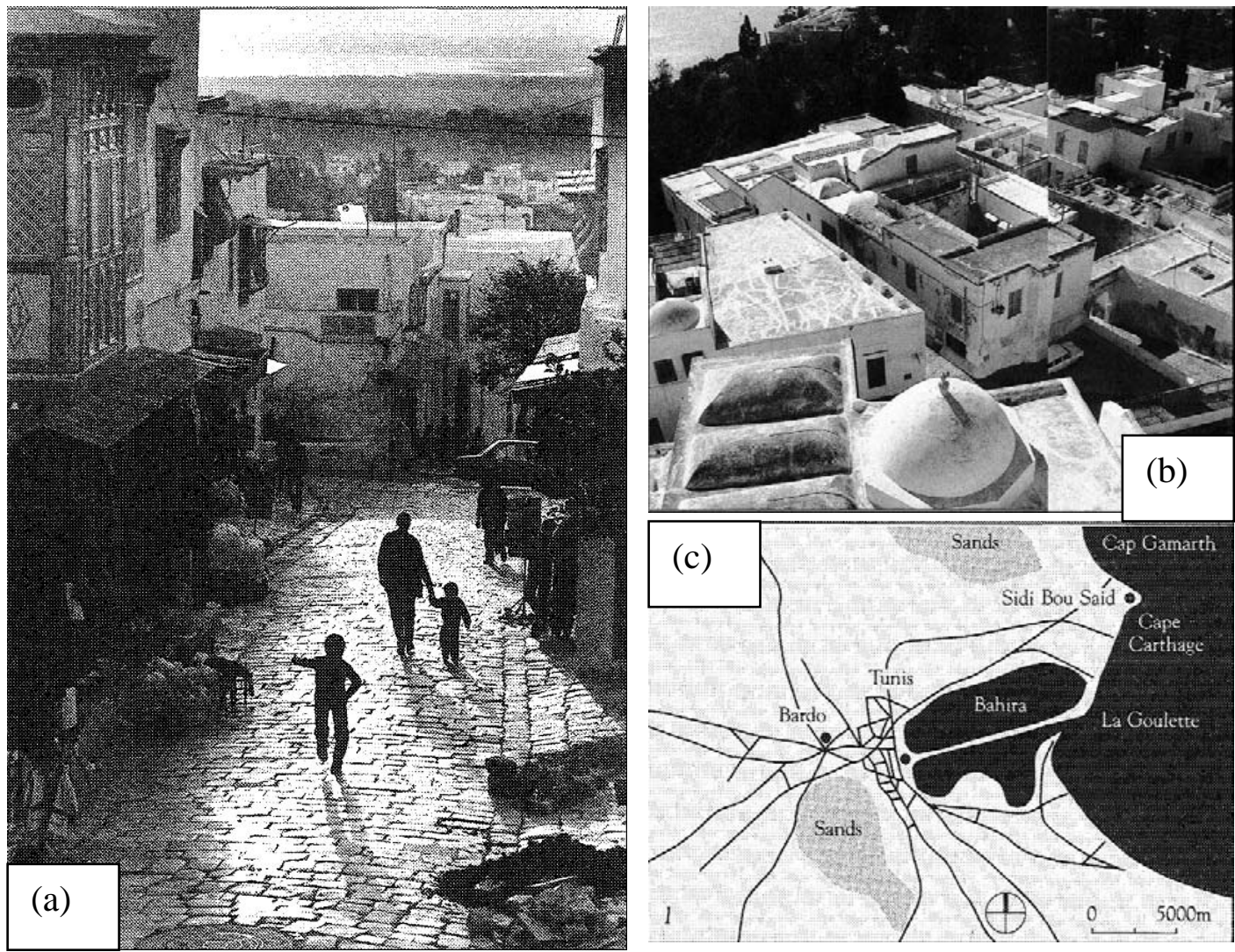

Figure 6. (a) View from the café overlooking the souq; streets and semipublic spaces between buildings provide areas for positive social interaction; (b) View to the sea from the minaret of the mosque and shrine of Sidi Bou Said; (c) Tunis Region map depicting Sidi Bou Said and Proximity to Cape Carthage archaeological site, (From: Holod, Renata and Darl Rastorfer. 1983)

\subsection{Rehabilitation of Hebron Old Town, Hebron, Palestine Completed in 1995 and ongoing}

Hebron, an old and sacred town $32 \mathrm{~km}$ to the south of Jerusalem, is a very important religious centre for Islam, Judaism, and Christianity. (Davidson, ed.,1998) The ancient city lies to the south-east of the modern turn-of-the-century city, and possesses a remarkable stone architecture evidenced in Figure 7, most of which was built in the 18th Century. Since its occupation by Israel in 1967, 
Hebron has been a focus of Jewish settlement. Almost a decade ago, the Hebron Rehabilitation Committee was created, as a result of a decision by Yasser Arafat, to develop a programme to renew the town for Palestinian habitation In January 1997, Israel turned over 80 percent of the administration of Hebron to the Palestinian Authority, thereby enabling the actual reconstruction of the old town to begin.
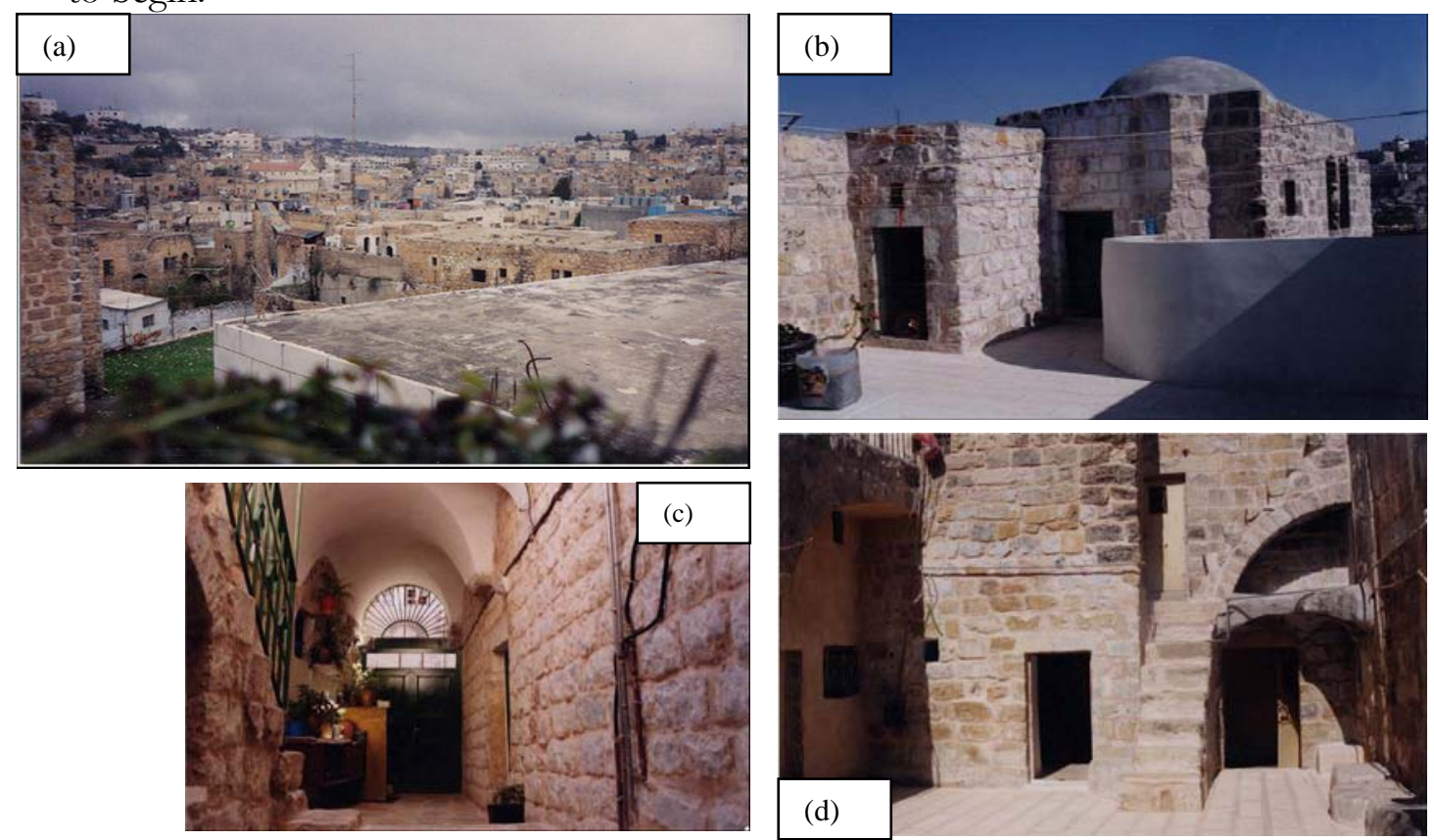

Figure 7. (a) Overview of Hebron old town; (b, c, \& d) Photos depicts finished work; photo Courtesy: the Architect, the Aga Khan Award available at: http://archnet.org/library/files/one-file.jsp?file_id=567

The sector under revitalisation consists of large, extended-family houses built of thick stone walls with vaulted superstructures and arranged in a compact urban texture. Most of the clusters do not suffer from major structural problems. No extensive reconstruction is contemplated, only work necessary to make them structurally sound and functional (Davidson, ed.,1998). The rehabilitation includes running water, sewage, and drainage services. The jury notes "the skills, competence, and courage of the community, as well as the architectural relevance of the work and the promising future of the rehabilitated city", and that "this approach is valid for urban situations in many other parts of the world."

\subsubsection{Plans to Conserve the Old City, Hebron Rehabilitation Committee}

Conserving Hebron's Old City and developing the surrounding regions are a top priority for institutions operating in the city. HRC endeavoured to restore complete neighbourhoods in preparation of returning them to normal day- 
to-day life. Hebron's municipality worked on developing the infrastructure in the city, while government and community institutions strove to provide the necessary services to the Old City and its inhabitants, within the limits of available resources. (Yavuz, 1998) The Old City conservation project aims to present an integrated plan to safeguard the historic centre of the City of Hebron and create the means to guarantee its economic and social revival and to integrate it with the rest of the city's fabric. It especially seeks to present a planning framework entitled "detailed project to conserve and develop the Old City", based on protecting the traditional architectural fabric. It also seeks to generate friendly conditions to attract new residents and investors interested in developing this historic region.

HRC collaborated with Riwaq - Centre for the Conservation of Architectural Heritage in the Old City - in an experience which may be considered an achievement for both of them, with HRC obtaining a concept for conserving the Old City, which details the general trends of its present and future action, while Riwaq contributed to explaining the historic preservation of a very important Palestinian region. Planners and project workers acquired new experience in the practical implementation of theoretical concepts. This represents a great enrichment of Palestine's modern experience in this regard. The plan included the development of important sectors in and around the Old City.

Since the Old City lies in the middle of town, not all aspects of development could be discussed, and some were postponed to a later phase. The conservation plan produced a sequence of projects covering the development plan over the next ten years. (Yavuz, 1998). This plan will be reviewed every five years and a rolling plan will be devised to guarantee continued development over a period of 25 years.

\section{Cross Case Analysis}

In the following section a cross case analysis is carried out for the six case studies investigated in this paper. A technical review underlying urban conservation is carried out looking at seven main aspects which are: the type of project; the local architecture; the local climate; site topography; general objectives of the project; functional requirements and design concepts. 
Table 1: The conservation of Historic Areas; Response to historic area issues using three different sets of conservation project proposals and objectives

\begin{tabular}{|c|c|c|c|c|c|c|}
\hline $\begin{array}{c}\text { PROJECT } \\
\text { PROPOSALS / } \\
\text { TECHNICAL } \\
\text { REVIEW } \\
\text { UNDERLYING } \\
\text { URBAN } \\
\text { CONSERVATION }\end{array}$ & $\begin{array}{l}\text { AL DARB AL } \\
\text { ASFAR }\end{array}$ & DARB QIRMIZ QUARTER & $\begin{array}{l}\text { RESTORATION OF } \\
\text { BUKHARA OLD } \\
\text { CITY }\end{array}$ & $\begin{array}{l}\text { RECONSTRUCTION } \\
\text { OF HAFSIA QUARTER } \\
\text { II }\end{array}$ & $\begin{array}{l}\text { CONSERVATION OF } \\
\text { SIDI BOU SAÏD }\end{array}$ & $\begin{array}{l}\text { REHABILITATION OF } \\
\text { HEBRON OLD TOWN }\end{array}$ \\
\hline Type of Project & $\begin{array}{l}\text { Restoration, } \\
\text { Conservation }\end{array}$ & $\begin{array}{l}\text { Restoration, } \\
\text { Conservation }\end{array}$ & $\begin{array}{l}\text { Restoration, } \\
\text { Reconstruction }\end{array}$ & Reconstruction & Conservation & $\begin{array}{r}\text { Rehabilitation, } \\
\text { Reconstruction, } \\
\text { Revitalization }\end{array}$ \\
\hline $\begin{array}{c}\text { Local } \\
\text { Architecture }\end{array}$ & $\begin{array}{r}\text { Buildings average } \\
\text { of } 12 \text { to } 15 \mathrm{~m} \text {. The } \\
\text { walls of the houses } \\
\text { were built of half } \\
\text { timbered } \\
\text { construction of an } \\
\text { infilling of brick } \\
\text { and rubble. Roofs } \\
\text { and floors of } \\
\text { shaped wooden } \\
\text { beams. Small } \\
\text { windows and } \\
\text { mashrabiyas are } \\
\text { predominant. }\end{array}$ & $\begin{array}{r}\text { Buildings are an average of } \\
15 \mathrm{~m} \text { high. Monuments are } \\
\text { constructed of stone faced } \\
\text { walls, with a core of } \\
\text { poorer rubble material. } \\
\text { Upper levels of } \\
\text { monuments are sometimes } \\
\text { constructed in brick. } \\
\text { Floors often of patterned } \\
\text { marble or stone slabs. } \\
\text { Domestic buildings of } \\
\text { poorer quality materials } \\
\text { with same height. }\end{array}$ & $\begin{array}{r}\text { Brick with low } \\
\text { skyline } 2 \text { or } 3 \\
\text { storeys, interrupted } \\
\text { by tall minarets. } \\
\text { Sections of town } \\
\text { walls and gates } \\
\text { survived, rest was } \\
\text { destroyed }\end{array}$ & $\begin{array}{r}\text { It's a city of varied } \\
\text { style, Hafsid } \\
\text { stonework inspired } \\
\text { minarets and ceramic } \\
\text { panels along with } \\
\text { white washed facades } \\
\text { seems harmonious as } \\
\text { part of Tunisian art } \\
\text { and architecture, } \\
\text { alongside Andalusian } \\
\text { green tiled domes. } \\
\text { Climatic influences } \\
\text { appeared in loggias, } \\
\text { terraces and balconies. }\end{array}$ & $\begin{array}{l}\text { A rich mixture of } \\
\text { mauresque and some } \\
\text { 'italianizing' elements } \\
\text { organized around the } \\
\text { main landmarks, the } \\
\text { mosque and tomb of } \\
\text { "Cheikh Bou Said. } \\
\text { Developed to be a } \\
\text { summer resort for } \\
\text { the rich with lovely } \\
\text { gardens, white } \\
\text { washed walls, narrow } \\
\text { windows, } \\
\text { mashrabiyas, domes } \\
\text { and vaults are most } \\
\text { predominant. }\end{array}$ & $\begin{array}{l}\text { Dating back to the } 18^{\text {th }} \\
\text { century, a remarkable } \\
\text { stone architecture of } \\
\text { tightly knit clusters of } \\
\text { irregularly arranged } \\
\text { cubic volumes. Houses } \\
\text { usually; have } 2 \text { or } 3 \\
\text { storey, whose spaces are } \\
\text { asymmetrically clustered } \\
\text { around a courtyard, with } \\
\text { windows that have no } \\
\text { frames or glass panes, } \\
\text { only timber shutters, } \\
\text { opening on courtyards } \\
\text { and its semi opened } \\
\text { vertical extension. }\end{array}$ \\
\hline Local Climate & $\begin{array}{l}\text { Mild in winter with } \\
\text { occasional rains, } \\
\text { with hot summers. }\end{array}$ & $\begin{array}{r}\text { Mild in winter with } \\
\text { occasional rains, with hot } \\
\text { summers. }\end{array}$ & $\begin{array}{r}\text { Dry arid climate, } \\
\text { hot summers up to } \\
40^{\circ} \mathrm{C} \text { and summers } \\
20-23^{\circ} \mathrm{C} .\end{array}$ & $\begin{array}{r}\text { Mediterranean semi- } \\
\text { arid climate }\end{array}$ & $\begin{array}{r}\text { Mediterranean semi- } \\
\text { arid Climate }\end{array}$ & $\begin{array}{r}\text { Receives a fair amount } \\
\text { of rainfall, still has a } \\
\text { shortage of water, } \\
\text { average winter temp. } \\
10^{\circ} \mathrm{C} \text { and } 28^{\circ} \mathrm{C} \text { in } \\
\text { summer. }\end{array}$ \\
\hline Site Topography & A flat sit & $\begin{array}{r}\text { The site appears flat, but } \\
\text { has a gentle fall from east } \\
\text { to west and from north to } \\
\text { south. }\end{array}$ & $\begin{array}{r}\text { Flat plain and semi } \\
\text { desert lands }\end{array}$ & $\begin{array}{r}\text { Tunis is located on a } \\
\text { rather flat site, with a } \\
\text { slope of } 1 \% \text { from west } \\
\text { to east, with Hafsia on } \\
\text { the northern eastern }\end{array}$ & $\begin{array}{r}\text { Built on a hill above } \\
\text { a magnificent cliff } \\
\text { and the bay of } \\
\text { Carthage. }\end{array}$ & $\begin{array}{l}\text { The highest town in } \\
\text { Palestine, it is the base } \\
\text { and lower slopes of the } \\
\text { four mountains that } \\
\text { surrounds it. }\end{array}$ \\
\hline
\end{tabular}




\begin{tabular}{|c|c|c|c|c|c|c|}
\hline & & & & $\begin{array}{r}\text { edge, on low grounds } \\
\text { towards which storm } \\
\text { water would normally } \\
\text { flow. }\end{array}$ & & \\
\hline $\begin{array}{l}\text { General } \\
\text { Objectives }\end{array}$ & $\begin{array}{r}\text { To adopt an } \\
\text { integrated urban } \\
\text { conservation } \\
\text { project. } \\
\text { Restoration of the } \\
3 \text { listed houses in } \\
\text { the area, while } \\
\text { improving the } \\
\text { surroundings. } \\
\text { Electricity, water, } \\
\text { and sewage } \\
\text { systems were } \\
\text { renovated. }\end{array}$ & $\begin{array}{r}\text { Rehabilitating an ancient } \\
\text { quarter in the Fatimid city } \\
\text { of Cairo, via conserving } \\
\text { the seven listed } \\
\text { monuments and then } \\
\text { rehabilitating all the } \\
\text { houses in the quarter. }\end{array}$ & $\begin{array}{r}\text { Revitalising the } \\
\text { historic centres of } \\
\text { the old town, via } \\
\text { restoration, } \\
\text { reconstruction or } \\
\text { upgrading of the } \\
\text { monuments and } \\
\text { proper reuse. }\end{array}$ & $\begin{array}{l}\text { The recreation of the } \\
\text { traditional urban } \\
\text { fabric and upgrading } \\
\text { the infrastructure. } \\
\text { Rehabilitation of } 600 \\
\text { housing units along } \\
\text { with the construction } \\
\text { of } 400 \text { housing, } \\
\text { commercial and office } \\
\text { units. Maintaining a } \\
\text { harmonious } \\
\text { relationship with the } \\
\text { existing morphology } \\
\text { of the old city. }\end{array}$ & $\begin{array}{r}\text { To manage the scale } \\
\text { and structure of the } \\
\text { village, and preserve } \\
\text { its historical basic } \\
\text { pattern and } \\
\text { morphology. The } \\
\text { first decree of } \\
\text { restoration and } \\
\text { conservation signed } \\
\text { in } 1915 \text { and was } \\
\text { followed by other } \\
\text { decrees till } 1973 .\end{array}$ & $\begin{array}{r}\text { To bring back life to the } \\
\text { old city as well as } \\
\text { preserve it culture and } \\
\text { architecture. To restore } \\
\text { the old town buildings, } \\
\text { alleys and small shops } \\
\text { and bring the dwellings } \\
\text { up to contemporary } \\
\text { standards of habitation. } \\
\text { To counteract the } \\
\text { political pressure to } \\
\text { evacuate the old town } \\
\text { and to avoid its } \\
\text { becoming a target for } \\
\text { Israeli settlement. }\end{array}$ \\
\hline $\begin{array}{c}\text { Functional } \\
\text { Requirements }\end{array}$ & $\begin{array}{r}\text { Rehabilitation and } \\
\text { restoration of the } \\
\text { Darb alsfar } \\
\text { quarter. Allocating } \\
\text { proper functions } \\
\text { to houses restored } \\
\text { to reflect the } \\
\text { cultural implication } \\
\text { they are required } \\
\text { to reflect. }\end{array}$ & $\begin{array}{l}\text { Rehabilitation and } \\
\text { revitalization of the whole } \\
\text { ancient Fatimid city. } \\
\text { Retaining authenticity in } \\
\text { the area. Most of the } \\
\text { buildings within the } \\
\text { quarter either are used as } \\
\text { their original function as } \\
\text { the mosques or a proper } \\
\text { new function have been } \\
\text { designated to them. }\end{array}$ & $\begin{array}{r}\text { Had to be restored } \\
\text { and provided with } \\
\text { basic utilities. Most } \\
\text { importantly new } \\
\text { proper function, as } \\
\text { no practicing } \\
\text { Muslims were left } \\
\text { after Soviet rule. } \\
\text { Buildings that } \\
\text { survived was } \\
\text { Mosques and } \\
\text { khanqas. }\end{array}$ & $\begin{array}{r}\text { An infrastructure } \\
\text { development } \\
\text { involving installation } \\
\text { and improvements to } \\
\text { street networks, } \\
\text { utilities and services. A } \\
\text { rehabilitation } \\
\text { component involving } \\
\text { restoration, reuse and } \\
\text { upgrading of decayed } \\
\text { structures. } \\
\text { Reconstructing } \\
\text { buildings on vacant } \\
\text { land and on sites } \\
\text { cleared by demolition. }\end{array}$ & $\begin{array}{r}\text { Has to be restored } \\
\text { and to consider mass } \\
\text { tourism. To consider } \\
\text { its limit road to } \\
\text { Carthage } \\
\text { archaeological site. } \\
\text { Considering the } \\
\text { social and economic } \\
\text { structure for future } \\
\text { developments. Some } \\
\text { of the old houses } \\
\text { were turned into } \\
\text { touristic hotels. }\end{array}$ & $\begin{array}{r}\text { No extensive } \\
\text { construction and } \\
\text { minimum amount of } \\
\text { work to make dwellings } \\
\text { structurally sound again. } \\
\text { Main interventions } \\
\text { include the provision of } \\
\text { extra stairs when the } \\
\text { present one doesn't suit } \\
\text { its function or structure. } \\
\text { Addition of running } \\
\text { water, electricity, or } \\
\text { other infrastructures. } \\
\text { Repairing or altering } \\
\text { spaces to fit new } \\
\text { plumbing or life styles. }\end{array}$ \\
\hline Design Concepts & $\begin{array}{l}\text { 1. Project adopts } \\
\text { implicitly the } \\
\text { integrated urban }\end{array}$ & $\begin{array}{l}\text { 1. Replacement of } \\
\text { all stones which have } \\
\text { become corroded. }\end{array}$ & $\begin{array}{l}\text { 1. Restoration } \\
\text { concentrated mainly } \\
\text { on the major }\end{array}$ & $\begin{array}{r}\text { 1. Detailed studies and } \\
\text { analysis for } \\
\text { infrastructure, }\end{array}$ & $\begin{array}{r}\text { 1. An integral } \\
\text { conservation that } \\
\text { merits its history, }\end{array}$ & $\begin{array}{l}\text { 1. No Radical changes } \\
\text { should be made to the } \\
\text { exterior facades, }\end{array}$ \\
\hline
\end{tabular}




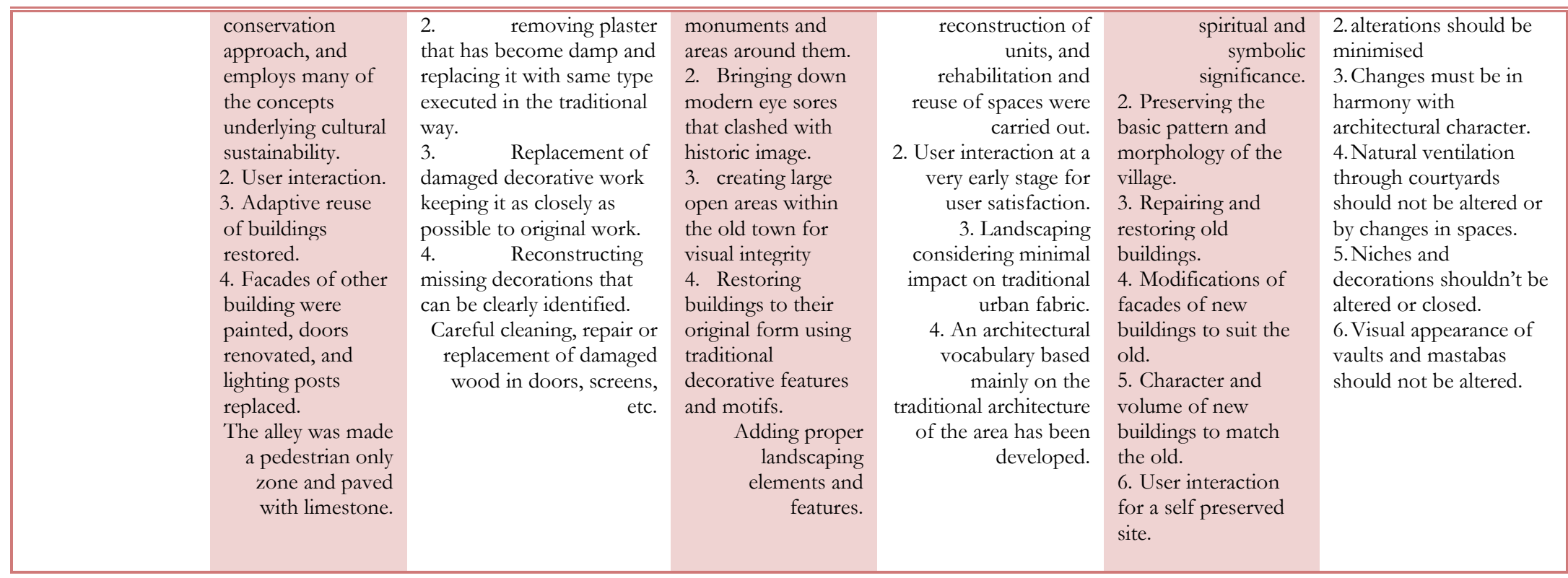




\section{Discussion and Conclusion}

There is an urgent requirement for rehabilitation and heritage conservation strategies which aims at sustaining the essential qualities of the historic sites in old cities along with the life of their resident communities. These strategies should adapt these physical structures while maintaining the everyday life of the people. This approach not only introduces new uses for historic heritage buildings which supports today's life style requirements but should also be able to provide for future generations to come. The intent of this paper is to highlight lessons that can be learned from looking at conservation projects of historic and heritage sites in Developing countries. The appropriate technical and social solutions provided by sustainable urban conservation of these projects are analysed in detail in the cross case analysis in the above section. Developing countries have high expectations out of the conservation projects and this can be seen in transformation carried out in the rehabilitation and conservation of some of their old towns and cities. Sustainable urban conservation has been addressed in a wide variety of projects in different contexts. The paper carried out a comparative analysis for some of the urban conservation projects awarded some prestigious awards like the Aga Khan and other national and international awards. The projects analysed identify a new architectural idiom and reflect the diversity of needs and resources within the Developing World.

By and large, the paper introduced a responsive scenario/agenda for cultural sustainability of historic cities. It examined and analyzed conservation and rehabilitation project proposals in four different countries as an exemplar for achieving high conservation and rehabilitation schemes in urban conservation efforts. These projects aimed at delineating the positive and negative aspects within the scope of social and cultural sustainability and based on a comprehensive approach for sustainable urban conservation. The success of these projects as discussed in earlier can be summed in some key aspects such as: public participation and awareness at early stages of the project; an implicit approach of integrated urban conservation; employing many of the concepts underlying cultural sustainability; preserving the basic pattern and morphology of the urban fabric and the use of space; minimal interventions following a scrutinized analysis and assessment of the monuments or buildings involved; a bottom up approach and involving all stakeholders from the beginning of the projects; restoring buildings to their original form using traditional decorative features and motifs. Another key feature that led to success of most of these revitalisation projects is high impact propaganda that helped in mobilizing and selling the idea of rehabilitation to the residents. 
Sustainable urban conservation of historic towns and cities is viewed as a comprehensive approach that integrates several processes that pertain to historic buildings and their physical urban context as presented in the examples analysed. These along with the socio/economic environment within which the city exists and operates. The paper envisaged that the problems of historical centres would not be solved by individual projects that focus on the conservation and rehabilitation of their architectural and urban spaces. Rather, they can be solved by those policies and concrete programs that address the needs of the inhabitants such as reducing poverty, increasing employment, upgrading local communal services, and most importantly, empowering and enabling the local inhabitants to positively participate in the planning and management of their environment. This is also to ascertain user satisfaction and sustainable continuing conservation of those sites. To be able to achieve this, it will be necessary to enable change in the political agenda and environment in which historical sites are rehabilitated and regenerated in the true essence. Concomitantly, policies and governmental practices should be modified accordingly.

It is envisioned that for successful sustainable urban conservation projects to take place it requires a lot than choosing the best conservation strategy, or relocation policies. It should involve educational and environmental campaigns to teach local communities the merits of conservation and to highlight the historical, functional, and ontological ties that bid them with their city. It should work on the development and assuring the sense of belonging to a place.

To conclude, some open ended and philosophical questions need to be addressed when we are dealing with sensitive historic sites:

- First; What are we trying to preserve? A number of major buildings? The urban character? A way of life?

- Second; Why do we want to preserve whatever it is we choose to preserve? Because it is part of our heritage? To improve the lot of inhabitants of the old city? Or to generate a new resource to earn money through tourism, retail or other activities?

- Third; Who are we preserving historic areas for? Are the present users to be the prime beneficiaries of the intervention? Or the country at large? Or is it being done for the sake of generations yet unborn? 
Depending on how the previous set of questions is answered, the responsibility for action and the type of intervention will differ dramatically. These interventions work in both developing and developed worlds. Unless these questions are answered, different parties will continue working in isolation, and will continue to talk at cross-purposes. We should be a culture that guarantees for the future. With all community work, and specifically with work related to historic context the social and cultural aspect and the beliefs of the people plays a major role in shaping those environments. It is indeed vital that with such community work, it is important to have a two-way channel of vision and not a one way approach. Some organizations should take these questions seriously and search for answers. Otherwise, historical and heritage sites will either disappear because of the uncoordinated efforts and the contradictory approaches to conservation, or will turn into an open air museum, perhaps physically pleasant, but socially lifeless.

\section{Acknowledgements:}

The Authors would like to thank Professor Ashraf Salama, Chair and Professor in architecture and currently the Head of the Department of Architecture and Urban Planning at Qatar University, for his valuable guidance and feedback within the early stages of this research.

\section{References}

Abada, G. (2000). Al Darb Asfar: Limited Restoration to Wider Conservation. Medina Magazine, Issue 13, May

Abdel Fattah, K., \& Abdelhalim, A. I. (1989). The rehabilitation and upgrading of Historic Cairo. In Aga Khan Award for Architecture. The expanding metropolis: Coping with the urban growth of Cairo (Vol. 1). (Conference papers).

Aboukorah, O. (2005) Between a Secular Management System and International Standards of Protection: The Heritage of Cairo's Old Quarter, Museum International, Vol. 57:1-2, p. 120-128

Aga Khan Award for Architecture (AKAA) (1980), Conservation of Sidi Bou Saïd, Tunisia, Planners: Technical Bureau of the Municipality (Sanda Popa), Tunis, Tunisia, Conservator: Abd El-Aziz Ben-Achour, Sidi Bou Saïd, Tunisia, Client: Municipality of Sidi Bou Saïd (M. Baly, Mayor), Sidi Bou Saïd, Tunisia, Completed: 1973 (ongoing)

Aga Khan Award for Architecture (AKAA) (1983), Darb Qirmiz Quarter, Cairo, Egypt, Restoration: Egyptian Antiquities Organization and German Archaeological Institute (Michael Meinecke, Philip Speiser, and Muhammad Fahmi Awad) Cairo, Egypt; Master Craftsmen: S.M. al-Habbal, S.H. Muhammad, and I. Abd alMun'im Cairo, Egypt; Client: Egyptian Antiquities Organisation, (Abd al-Tawab, 
Director of the Islamic Section), Cairo, Egypt, Completed:1980

Aga Khan Award for Architecture (AKAA-a) (1995), Restoration of Bukhara Old City, Bukhara, Uzbekistan“, Restoration: Restoration Institute of Uzbekistan, Tashkent and Restoration Office of the Municipality of Bukhara, Uzbekistan, Client: Municipality of Bukhara, Uzbekistan Completed: 1975 and ongoing

Aga Khan Award for Architecture (AKAA-b) (1995), Reconstruction of Hafsia Quarter

II, Tunis, Tunisia, Planners: Association de Sauvegarde de la Médina (ASM) Tunis, Tunisia, Client: Municipality of Tunis, Tunisia, Developer: Agence de Réhabilitation et Rénovation Urbaine (ARRU), Completed: 1986

Aga Khan Trust For Culture, Cultural Services Egypt (AKCS-E) (2003): Darb Al-Ahmar Base- line Survey

Aga Khan Trust For Culture (AKTC) (2005): Cairo: Urban Regeneration in the Darb AlAhmar District. Geneva

AlRadi, S., (1995), Technical review of Bukhara Old City Restoration, the Aga Khan Award for Architecture, Text Report, available at: http://archnet.org/library/files/one-file.jsp?file_id=871

American Heritage Dictionary, (AHD, Editors) (2005), The American Heritage ${ }^{\circledR}$ Science Dictionary, Houghton Mifflin Harcourt Company, Library of congress cataloging in Publication Data.

Andreae, S, (1996), From comprehensive development to Conservation Areas. In Preserving the Past, ed M Hunter, pp 135-155. Alan Sutton, Stroud, Glos.

Antoniou, J., (2004): Cairo's Urban Growth and its Impact on the Historic City. In: Bianca, Stefano; Jodidio, Philip (Hg.): Cairo - Revitalising a Historic Metropolis. S.31-41. Accessed at: www.archnet.org/library/documents/one-docu mentjsp?document- id=9584; Accessed on: 29.11.2009

Appleyard, D. (1977), Urban Conservation in Europe and America: Planning, Conflict, and Participation in the Inner City. European Regional of Fullbright Commissions. Rome.

Appleyard, D., ed., (1979), The Conservation of European Cities. Cambridge, Mass: MIT Press.

Ashworth, G J, (1997), Conservation as preservation or as heritage: two paradigms and two answers. Built Environment 23(2), 92-102.

Bianca, Stefano (1994): The Historic Cities Sup- port Programme of the Aga Khan Trust for Culture. In: Trialog, Heft 40, S.14-18

Bianca, S. (2000) Urban Form in the Arab World: Past and Present (Thames and Hudson)

Bianca, S. (2004) A New Path to Urban Rehabilitation in Cairo in Bianca, Stefano et al. (eds) Cairo: Revitalizing a Historic Metropolis (Umberto Allemandi \& C. for Aga Khan Trust for Culture)

Bianca, S. \& Siravo, F. (eds.), (2005), Cairo: Urban Regeneration in the Darb al-Ahmar District. A Framework for Investment. Artemide Edizioni s.r.l. Rome: The Aga Khan Trust for Culture. www.akdn.org

Campbell, R. and Comodromos, D. (1999), "Urban Morphology + The Social Vernacular 
A Speculative Skyscraper for Islamic Medieval Cairo," Rensselaer Polytechnic Institute, pp.9-10.

Convention for the Safeguarding of the Intangible Cultural Heritage (2003)

Davidson, C., (1995), Reconstruction of the Hafsia Quarter II. In Architecture Beyond Architecture. Cynthia C. Davidson, and Ismail Serageldin, eds. London: Academy Editions.

Davidson, C., ed. (1998). "Rehabilitation of Hebron Old Town". In Legacies for the Future: Contemporary Architecture in Islamic Societies. London: Thames and Hudson, 38-53.

Elnokaly, A., Elseragy, A., Alsaadani, S., (2007), The Reflection of Euro- Mediterranean Historical Culture on Contemporary Architecture in Alexandria; EuroMediterranean Regional Conference, Proceedings of Traditional Mediterranean Architecture. Present and Future", Rehabimid, 12-15 July 2007, Barcelona, Spain.

Fadel, R., (1995), Technical review of Hafsia Quarter II Reconstruction, The Aga Khan Award for Architecture, Text Report, available at: http://archnet.org/library/files/one-file.jsp?file_id=1126

Feilden, B. M. (1982). Conservation of Historic Buildings. London. UK Butterworth Scientific.

Graber, O. (1993), "Why History: the Meanings and Uses of Tradition", Traditional Dwellings and Settlements Review 4, 2 (1993), pp. 19-26.

Hakim, B. (2001) Reviving The Rule System: An Approach For Revitalizing Traditional Towns In Maghrib, Cities, Vol. 18: 2, p. 87-92

Hampikian, N., 1999, Challenges Facing Conservation Projects in Historical Cairo. 9th Conference of Union of Egyptian Architects. Architectural Heritage and Urban Development. Cairo/Egypt.

Heidegger, M., (1951) "Building Dwelling Thinking”, in D.F. Krell, ed., Martin Heidegger: Basic Writings (London: Routledge, 1993).

Holod, R. and Darl R., (1983), Sidi Bou Said. In Architecture and Community. Renata Holod and Darl Rastorfer, eds. New York: Aperture

ICOMOS, The Venice Charter (ICOMOS, Venice, (1994)); United Nations Educational, Social and Cultural Organisation, Convention Concerning the Protection of the World Cultural and Natural Heritage (UNESCO, Paris, 1972); United Nations Educational, Social and Cultural Organisation, Recommendations Concerning the Safeguarding and Contemporary Role of Historic Areas (UNESCO, Nairobi, 1976); and International Commission on Monuments and Sites, The Charter for the Conservation of Historic Towns and Urban Areas (ICOMOS, Toledo, 1986).

Kern, S., (2003) The Culture of Time and Space: 1880-1918, second ed. (Cambridge, MA: Harvard University Press, 2003), p.139.

McDonald, S., Malys, N. and Maliene, V., (2009), "Urban Regeneration for Sustainable Communitites: A Case Study," Technological and Economic Development of Economy, Baltic Journal on Sustainability, 15 (1): pp49-59.

Raymond, A. (2001) Cairo: City of History (The American University in Cairo Press)

Rodenbeck, J. (1983). Urban conservation: its realities and the role it offers social 
research. In R. Lobban (Ed.), Urban research strategies for Egypt. Cairo Papers in Social Science (Vol. 6 (2), pp. 22-34). Cairo: American University in Cairo Press.

Rodwell, D. (2007) Conservation and Sustainability in Historic Cities (Blackwell Publishing)

Salama, A, (2000), Cultural Sustainability Of Historic Cities: Notes On Conservation Projects In Old Cairo, Registration Number 103, IAPS-16, Paper presented at: IAPS 2000 Conference METROPOLIS 21st Century: Cities, Social Life, and Sustainable Development, Paris, France 4 / 7 July 2000

Sedky, A. (2009) Living with Heritage in Cairo: Area Conservation in the Arab-Islamic City (The American University in Cairo Press)

Shehayeb D. \& Abdel Hafiz M. (2006). Tradition, Change, and Participatory Design: Redesigning Tablita Market in HistoricCairo. Open House International, 31(4):6776.

ShehAyeb, D. \& Eid, Y. (2007). Neighbourhood Design and Community Building: A model of social interaction. In D. Shehayeb, H. Turgut yildiz, \& P. Kellett (Eds.), The Appropriate Home: Can We Design "Appropriate" Residential Environments? Proceedings of the First HBNRC \& IAPS-CSBE Network Joint Symposium. p. 131-144.

Serageldin, I. (2000). Organizing Conservation: A proposal for Restoring Historic Cairo. Medina Magazine, Issue 13, May.

Stewart, D. J. (1999) Changing Cairo: The Political Economy Of Urban Form, International Journal of Urban \& Regional Research, Vol. 23:1, p. 128-146

Stren, R. and Polese, M., (2000), The Social Sustainability of Cities: Diversity and the Management of Change, Toronto University Press, Toronto.

Steinberg, F., (1996) Conservation and Rehabilitation of Urban Heritage in Developing Countries, HABITAT INTL. Vol. 20, No. 3, pp. 463-475

Sutton, K. and Fahmi, W. (2002), The rehabilitation of Old Cairo, Habitat International, Vol. 26: 1, p. 73-93

Tiesdell, S, Oc, T. and Heath, T. (1996) Revitalizing Historic Urban Quarters (Architectural Press)

The Arab Bureau for Design and Technical Consultations/K. Abdel-Fattah and A.I. Abdelhalim, "The Rehabilitation and Upgrading of Historic Cairo", in Aga Khan Award for Architecture (1984),

The Australia ICOMOS Charter for Places of Cultural Significance, Burra Charter (1979, Amended 1999)

Lewcock, R., (1983), Technical Review of Darb Qirmiz Quarter Restoration Project, the Aga Khan Award for Architecture ,Text Report, available at: http:/ / www.archnet.org/library/sites/one-site.jsp?site id=224

Lewcock, R., (1984) "Conservation in Islamic Cairo" in Aga Khan Award for Architecture, The Expanding Metropolis: Coping with the Urban Growth of Cairo, Proceedings of Seminar Nine (Aga Khan Award for Architecture/Concept Media, Singapore, 1984), pp. 49-53 
Lewcock, R., AbdeI-Fattab, K. and Abdelhalim, A.I. (1984), "The Rehabilitation and Upgrading of Historic Cairo" in Aga Khan Award for Architecture, The Expanding Metropolis: Coping with the Urban Growth of Cairo, Proceedings of Seminar Nine (Aga Khan Award for Architecture/Concept Media, Singapore, 1984), pp. 54-90.

Lichfield, N., (1988) Economics in Urban Conservation (Cambridge University Press, Cambridge.

Raymond, A. (1994) Islamic city, Arab city: Orientalists Myths and Recent Views, British Journal of Middle Eastern Studies, Vol. 21: 1, p. 3-18

Williams, C. (2002 A) Islamic Monuments in Cairo: The Practical Guide (The American University in Cairo Press)

Williams, C. (2002 B) Transforming the Old: Cairo's New Medieval City, Middle East Journal Vol. 56: 3, p.457- 475

Yavuz, A., (1998), Technical review of Hebron Old Town Rehabilitation, text report. Accessed at: http://archnet.org/library/files/one-file.jsp?file_id=564, Accessed on 20January 2011 